\title{
Vulnerability assessment of the port and coastal infrastructure facilities of TRINMAR, on the Gulf of Paria, Trinidad, to sea level rise
}

\author{
B. Singh ${ }^{1}$, A. El Fouladi ${ }^{1} \&$ K. Ramnath ${ }^{2}$ \\ ${ }^{1}$ Département de géographie, Université de Montréal, Montréal, QC, \\ Canada \\ ${ }^{2}$ HSE, Petrotrin, Trinidad and Tobago
}

\begin{abstract}
On account of the growth and expansions in the oil and gas sectors, TRINMAR, the marine arm of PETROTRIN, the state-owned oil and gas company of Trinidad and Tobago is required to move its port facilities from its current location at Point Fortin to a location $7 \mathrm{~km}$ south, namely Mont Pellier estate on Irois Bay in the Gulf of Paria. This paper addresses the vulnerability of the Mont Pellier site to rising sea levels, as caused by climate change. Sea level scenarios are created from the outputs of two coupled atmosphere-ocean geneneral ciculation models (A-OGCM's), namely the Canadian (CGCM1) and British (HadCM3) models. Photogrammtric and field surveys are used to create a Digital Elevation Model (DEM) of the study area. Future scenarios of sea level rise over the short (2031), medium (2051) and long (2071) terms, coupled with estimations of accelerated erosion rates based on the Bruun principle, are then used to assess the vulnerability of the port and built infrastructure to future sea levels. In light of these vulnerability assessments, adaptation measures are proposed to minimise the impacts of future sea levels on the Mont Pellier port and harbour facilities.
\end{abstract}

Keywords: climate change, sea level rise, impacts, vulnerability, coastal zone, port and harbour facilities.

\section{Introduction}

The Petroleum Company of Trinidad and Tobago (PETROTRIN) proposes to relocate its Trinmar Marine Base to the Mont Pellier Estate which is $7 \mathrm{Km}$ South 
West of the existing site at Point Fortin in the Gulf of Paria, fig 1. The project requires that an Environmental Impact Assessment (EIA) be done. An integral component of this EIA involves a Vulnerability Assessment of the proposed base facilities and operations to the impacts of future sea level rise deriving from greenhouse gas (GHG) climate change.

Greenhouse gas (GHG) climate change/global warming is one of the most pressing environmental concerns today IPCC [1]. Small Island States are highly vulnerable to climate change and sea level rise because of their small size and low elevation, as in the case of this study, which increases their sensitivity to climate change and limits their ability to adapt. In fact, adaptive capacity of human systems in Small Island States is generally low, and vulnerability high. Such Small Island States, as Trinidad and Tobago, are therefore likely to be among the countries most seriously affected by climate change and its impacts. Furthermore, sea level rise can severely impact upon coastal waters and coastal infrastructure, including ports and harbours, access roads and bridges and buildings, well into the future.

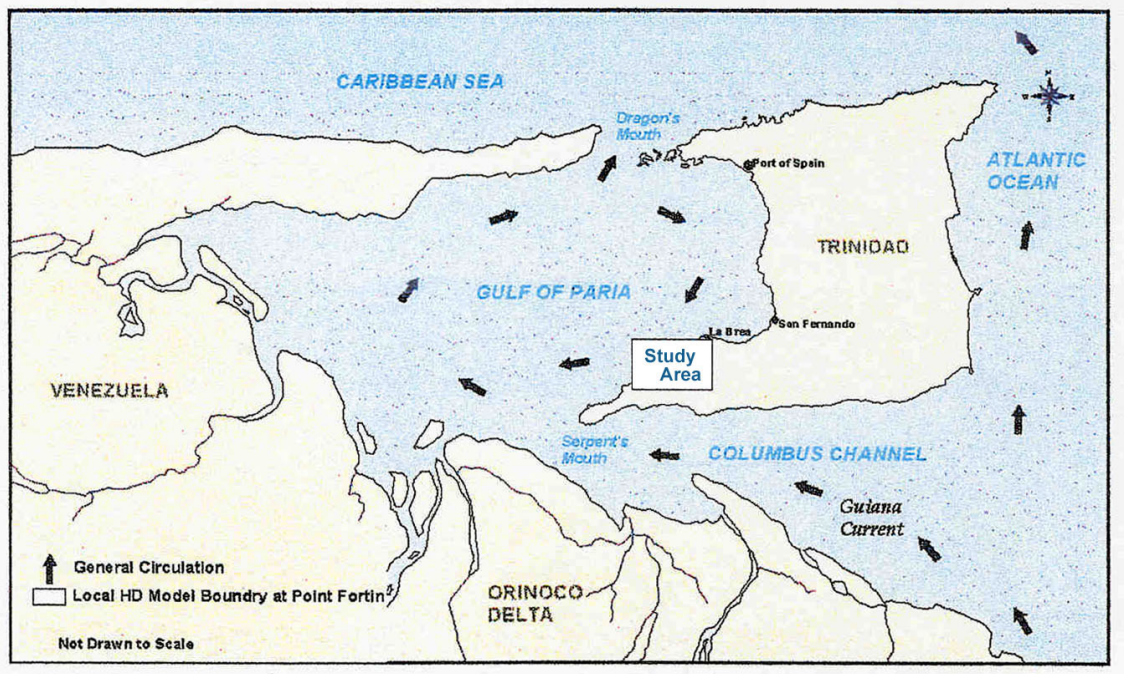

Figure 1: $\quad$ Location of study area.

\section{Scenarios of future sea level methods}

Scenarios of future climate and sea level, considering essentially thermal expansion, on a decadal basis, covering the period 1911 to 1971, are extracted from the most recent outputs of two coupled atmosphere-ocean general circulation models (A-OGCM'S), namely the Canadian (CGCM2) and British (HadCM3) models. However, other factors, such as melting of mountain and sub-polar glaciers, and, to a limited extent, the Greenland and Antarctic ice caps may further contribute to eustatic sea level rise, causing these estimates, based 
solely on thermal expansion to more than double (IPCC, 2001 a). Furthermore, crustal land movements that seem to be significant in the Gulf of Paria near the Mont Pellier site may further contribute to relative sea level rise, causing it to even exceed the rate of eustatic sea level rise (El Fouladi [2]).

Sea level rise is extracted from the Canadian CGCM2 model on a decadal basis, between 1911 and 2071, for two grid cells in the immediate vicinity of Trinidad. These simulations provide future sea level rise, based solely on thermal expansion, of roughly $25 \mathrm{~cm}$ in the near term (2031), of about $34 \mathrm{~cm}$ in the medium term (2051) and of approximately $51 \mathrm{~cm}$ in the long term (2071) (Singh and El Fouladi [3]). Sea level rise is also extracted from the British HadCM3 model on a decadal basis, between 1911 and 2071. Because of its finer spatial resolution, four grid cells in the immediate vicinity of Trinidad are selected. The HadCM3 simulations provide future sea level rise, based solely on thermal expansion, of about $14 \mathrm{~cm}$ in the near term (2031), of roughly $21 \mathrm{~cm}$ in the medium term (2051) and of approximately $24 \mathrm{~cm}$ in the long term (2071).

\subsection{Mapping sea level rise scenarios and impacts}

The focus of this paper is on future climate-driven sea level rise as determined from coupled atmosphere-ocean general circulation (A-OGCM) models, adjusted to take into account other factors that may be influencing relative sea level rise, and its impacts on built infrastructure at the proposed Trinmar base at Mont Pellier. Scenarios of eustatic sea level rise based mainly on thermal expansion, however do not capture the total magnitude of relative sea level rise. Based on field studies (Singh [4]; El Fouladi [2]), it is evident that factors, other than melting of land-based ice masses, related to vertical land movements and including tectonic activity, ocean bottom sediment loading, thermal and volcanic isostasy, can influence sea level rise. The influence of volcanic activity, thermal and sedimentary isostasy and post-glacial rebound, in the region of the Mont Pellier site on the Gulf of Paria, seem negligible, but sedimentary isostasy appears to be significant (El Fouladi [2]).

Of the total relative sea level rise observed, based on tidal gauge data at Port of Spain and Point Fortin of roughly 8 to $10 \mathrm{~mm} /$ year, the greatest contribution seems to come from continental dynamic factors, related to in large measure to plate tectonics and oil and gas exploration, as opposed to climate-driven oceanic dynamic factors. In the determination of relative sea level rise in the Gulf of Paria then, factors other than climate-driven sea level rise have to be taken into consideration (Singh and El Fouladi [3]; El Fouladi [2]).

\subsubsection{Relative sea level rise impacts: inundation and erosion}

Future sea level rise scenarios, used in mapping future rates of inundation and erosion at the Mont Pellier site, are estimated for the years centred around 2031, 2051 and 2071, using thermal expansion estimates of the Canadian (CGCM2) and British (HadCM3) coupled atmosphere-ocean general circulation models (AOGCM'S) as the basis, and adjusted upwards to account for melting of landbased ice (Table 1). 
Table 1: $\quad$ Estimates of future sea level rise for the area surrounding Trinidad using the CGCM2 and HadCM3 model outputs as a basis.

\begin{tabular}{|c|c|c|c|}
\hline Year & $\begin{array}{c}\text { Contribution-Thermal } \\
\text { Expansion }(\mathrm{cm})\end{array}$ & $\begin{array}{c}\text { Other Contributing } \\
\text { Factors }(\mathrm{cm})(1)\end{array}$ & $\begin{array}{c}\text { Final Value } \\
(\mathrm{cm})(2)\end{array}$ \\
\hline 2031 & HadCM3 $: 9.8$ & 13.5 & 14 \\
\hline 2051 & HadCM3 $: 14.9$ & 20.5 & 21 \\
\hline 2071 & HadCM3 $: 17.6$ & 24.2 & 25 \\
\hline 2031 & CGCM1 $: 18.2$ & 25.3 & 26 \\
\hline 2051 & CGCM1 $: 24.5$ & 33.7 & 34 \\
\hline 2071 & CGCM1 $: 36.8$ & 50.6 & 51 \\
\hline
\end{tabular}

(1) Multiply by 1.375 ; (2) Rounded value.

2.1.1.1 Digital Elevation Model (DEM) The methodology used for the simulation of the mean sea level impacts at the Mont Pellier Estate marine base is based on the construction of a Digital Elevation Model (DEM) of the land surrounding the site. The DEM is essentially a virtual representation of the terrain which permits us to analyze and visualize the behaviour and the spatial evolution of geographical and physical phenomena. In the case of this particular study, the DEM allows us to analyze marine intrusions due to eustatic and relative sea level rise, using different A-OGCM scenarios of sea level rise. The method essentially involves creating the DEM, and extracting, using the appropriate modules of the IDRISI Geographical Information System (GIS) software, the regions affected by sea level rise in the vicinity of the Mont Pellier site (Singh and El Fouladi [3]. The DEM is constructed from field topographic surveys in vectorial mode and from existing topographic maps of the area surrounding the proposed Trinmar marine base. When using the IDRISI GIS, these data are then pre-treated and then interpolated so as to attribute a numeric elevation to each point in the study area. The pre-treatment of the data is an operation that assures the linkage between the data collected and their analysis. Once the database on the elevation points is created, IDRISI is used to create the DEM of the area around the Mont Pellier site. We then exploited the classification and logical and arithmetic operations of IDRISI to extract the different layers corresponding to the scenarios of sea level rise. These layers are then judiciously juxtaposed to the DEM so as to geographically situate the eventual intrusions of the rising seas in vicinity of the Mont Pellier estate on the Gulf of Paria (Singh and El Fouladi [3]).

\section{Mapping sea level rise impacts: inundation and erosion}

Based on the sea level rise scenarios for the CGCM1 and HadCM3 climate models, as presented in Table 1, and applying them to the DEM created with IDRISI, we then derive the areas of coastland likely to be inundated in the vicinity of the proposed Trinmar marine base at the Mont Pellier Estate Paria (Singh and El Fouladi [3]). At first, using the CGCM1 scenario, by the year 2031, rising sea levels will encroach upon the site, mainly at its eastern flank at 
the mouth of the Cap-de-Ville River and at its western flank, near the Manifold location. Total land loss, based on the modelling results, due to inundation from rising sea levels, will be 4.47 hectares (Figure 2 and Table 2).

By the year 2051, applying the CGCM1 scenario, rising sea levels will continue to encroach upon the site, still mainly at its eastern flank at the mouth of the Cap-de-Ville River and at its western flank, near the Manifold location. Total land loss, based on the CGCM1 and DEM modelling results, due to inundation from rising sea levels by 2051, will be 4.68 hectares (Figure 3 and Table 2).

Finally, by the year 2071, applying the CGCM1 scenario, rising sea levels will further encroach upon the site, still mainly at its eastern flank at the mouth of the Cap-de-Ville River and at its western flank, near the Manifold location. Total land loss, based on the CGCM1 and DEM modelling results, due to inundation from rising sea levels by 2071, will be 5.01 hectares (Figure 4 and Table 2).

On the other hand, using the HadCM3 scenario, by the year 2031, rising sea levels will encroach upon the site in a similar manner, mainly at its eastern flank at the mouth of the Cap-de-Ville River and at its western flank, near the Manifold location. Total land loss, based on the modelling results of HadCM3 coupled with the DEM, due to inundation from rising sea levels, will be 4.12 hectares (Figure 5 and Table 3).

However, by the year 2051, applying the HadCM3 scenario, rising sea levels will also continue to encroach upon the site, still mainly at its eastern flank at the mouth of the Cap-de-Ville River and at its western flank, near the Manifold location. Total land loss, based on the HadCM3 and DEM modelling results, due to inundation from rising sea levels by 2051, will be 4.34 hectares (Figure 6 and Table 3).

Finally again, by the year 2071, applying the HadCM3 scenario, rising sea levels will continue to further encroach upon the site, still mainly at its eastern flank at the mouth of the Cap-de-Ville River and at its western flank, near the Manifold location. Total land loss, based on the HadCM3 and DEM modelling results, due to inundation from rising sea levels by 2071 , will be 4.44 hectares (Figure 7 and Table 3).

Thus, using both the CGCM1 and HadCM3 climate models, the relatively small amounts of land loss due to inundation from sea level rise is attributable to the fact that the area surrounding the Mont Pellier site between the Cap-de-Ville River and the Manifold is characterized by very steep slopes, which renders sea level rise impacts almost imperceptible (Singh and El Fouladi [3]).

However, when the additional effect of erosion, due to a combination of rising sea levels, wave attack and slumping of the steep clayey cliffs following heavy rains, is integrated into the simulations, the loss of land increases considerably. The added effect of erosion is based on an estimate of land retreat of 1.6 metres/year, which is similar to the Bruun principle (Bruun and Schwartz [5]).

Again, based on the sea level rise scenarios for the CGCM1 and HadCM3 climate models, as presented in Table 1 and the erosion rate of 1.6 metres/year, 
and applying them to the DEM created with IDRISI, we derive the areas of coastland likely to be inundated and eroded in the vicinity of the proposed Trinmar marine base at the Mont Pellier Estate site (Singh and El Fouladi [3]).

At first, using the CGCM1 scenario, by the year 2031, rising sea levels and erosional forces will allow the sea to encroach upon the site, mainly at its eastern flank at the mouth of the Cap-de-Ville River and at its western flank, near the Manifold location. At the Mont Pellier Estate site itself, close to one quarter of the land is lost. Total land loss, based on the modelling results, due to inundation from rising sea levels and erosional forces, will be 11.38 hectares (Figure 2 and Table 2).

By the year 2051, applying the CGCM1 scenario, rising sea levels combined with erosional effects, will continue to encroach upon the site, still mainly at its eastern flank at the mouth of the Cap-de-Ville River and at its western flank, near the Manifold location. At the Mont Pellier Estate site itself close to one half of the land area would likely be lost. Total land loss, based on the CGCM1 and DEM modelling results combined with the erosional effect, due to inundation and erosion from rising sea levels by 2051, will be 18.28 hectares (Figure 3 and Table 2).

Finally, by the year 2071, applying the CGCM1 scenario, rising sea levels combined with erosional forces, will further encroach upon the site, still mainly at its eastern flank at the mouth of the Cap-de-Ville River and at its western flank, near the Manifold location. At the Mont Pellier Estate site itself, close to two thirds of the land area would likely be lost. Total land loss, based on the CGCM1 and DEM modelling results combined with the erosional effect, due to inundation and erosion from rising sea levels by 2071, will be 24.71 hectares (Figure 4 and Table 2).

On the other hand, using the HadCM3 scenario, by the year 2031, rising sea levels and erosional forces will encroach upon the site in a similar manner, mainly at its eastern flank at the mouth of the Cap-de-Ville River and at its western flank, near the Manifold location. As was the case with the CGCM1 results, close to one quarter of the land at the Mont Pellier Estate site will likely be lost. Total land loss, based on the modelling results of HadCM3 coupled with the DEM and erosional forces, due to inundation and erosion deriving from climate change and rising sea levels, is 11.25 hectares (Figure 5 and Table 3 ).

By the year 2051, applying the HadCM3 scenario and the DEM, rising sea levels and erosional forces will continue to encroach upon the site, still mainly at its eastern flank at the mouth of the Cap-de-Ville River and at its western flank, near the Manifold location. Again, at the Mont Pellier Estate site itself, close to one half of the land area would likely be lost. Total land loss, based on the HadCM3 and DEM modelling, combined with erosional effect, due to inundation and erosion deriving from climate change and sea level rise by 2051, will be 18.24 hectares (Figure 6 and Table 3).

Finally, by the year 2071, applying the HadCM3 scenario and the DEM and integrating erosional effects, climate change and rising sea levels will continue to further encroach upon the site, still mainly at its eastern flank at the mouth of the Cap-de-Ville River and at its western flank, near the Manifold location. At the 
Mont Pellier Estate site itself, close to two thirds of the surface area is likely to be lost. Total land loss, based on the HadCM3, DEM and erosion modelling results, due to climate change and rising sea levels by 2071, will be 24.57 hectares (Figure 7 and Table 3).

It would appear then that both in the case of the CGCM1 and HadCM3 climate models, the main reason for the relatively large amounts of land loss due to inundation and erosion from climate change and sea level rise is that the area surrounding the Mont Pellier site between the Cap-de-Ville River and the Manifold is characterized by very steep clayey slopes, thus rendering climate change and sea level rise impacts very drastic.

Table 2: $\quad$ Estimates of coastal areas inundated due to future sea level rise for the Mont Pellier site using the CGCM2 and HadCM3 model outputs as a basis.

\begin{tabular}{lcc}
\hline & Number of pixels & Surface area (hectares) \\
\hline CGCM1 2031 & 44670 & 4.47 \\
CGCM1 2051 & 46804 & 4.68 \\
CGCM1 2071 & 50094 & 5.01 \\
HadCM3 2031 & 41187 & 4.12 \\
HadCM3 2051 & 43398 & 4.34 \\
HadCM3 2071 & 44435 & 4.44 \\
\hline
\end{tabular}

Table 3: Estimates of coastal areas inundated and eroded due to future sea level rise for the Mont Pellier site using the CGCM2 and HadCM3 model outputs.

\begin{tabular}{lcccc}
\hline & $\begin{array}{c}\text { SLR } \\
\text { Number of pixels }\end{array}$ & $\begin{array}{c}\text { SLR } \\
\text { Area (hectares) }\end{array}$ & $\begin{array}{c}\text { EROSION } \\
\text { Number of pixels }\end{array}$ & $\begin{array}{c}\text { EROSION } \\
\text { Area (hectares) }\end{array}$ \\
\hline CGCM1 2031 & 44670 & 4.47 & 113757 & 11.38 \\
CGCM1 2051 & 46804 & 4.68 & 182830 & 18.28 \\
CGCM1 2071 & 50094 & 5.01 & 247134 & 24.71 \\
HadCM3 2031 & 41187 & 4.12 & & \\
HadCM3 2051 & 43398 & 4.34 & 112526 & 11.25 \\
HadCM3 2071 & 44435 & 4.44 & 24572423 & 18.24 \\
\hline
\end{tabular}




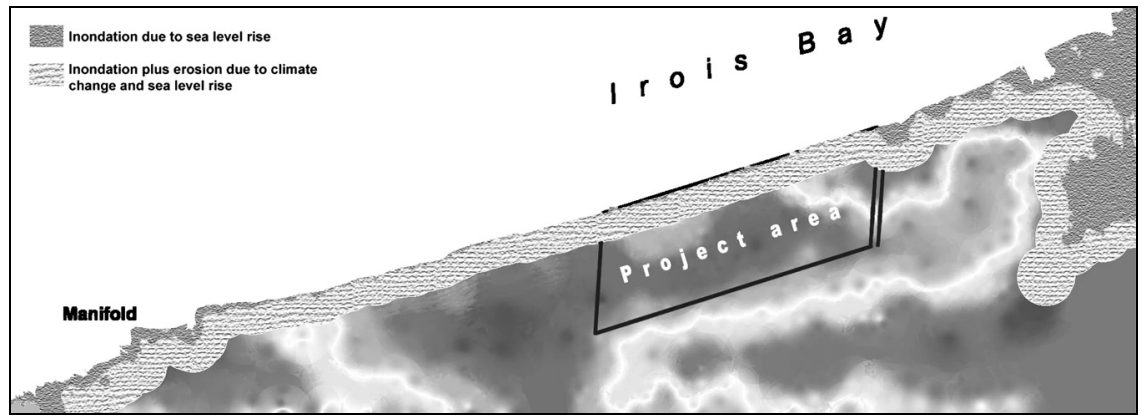

Figure 2: Inundation and erosion of the coastland at the Mont Pellier site due to sea level rise as simulated by CGCM1, coupled with the DEM, 2031.

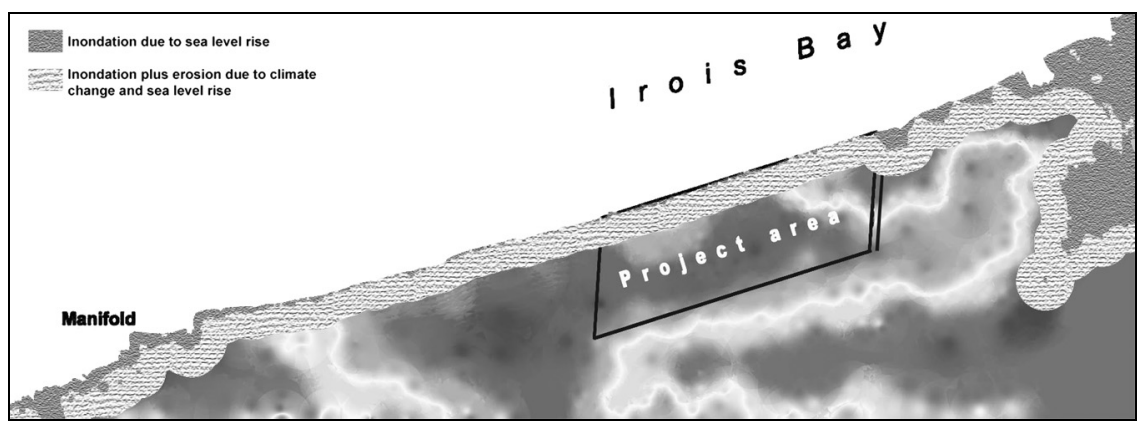

Figure 3: Inundation and erosion of the coastland at the Mont Pellier site due to sea level rise as simulated by CGCM1, coupled with the DEM, 2051 .

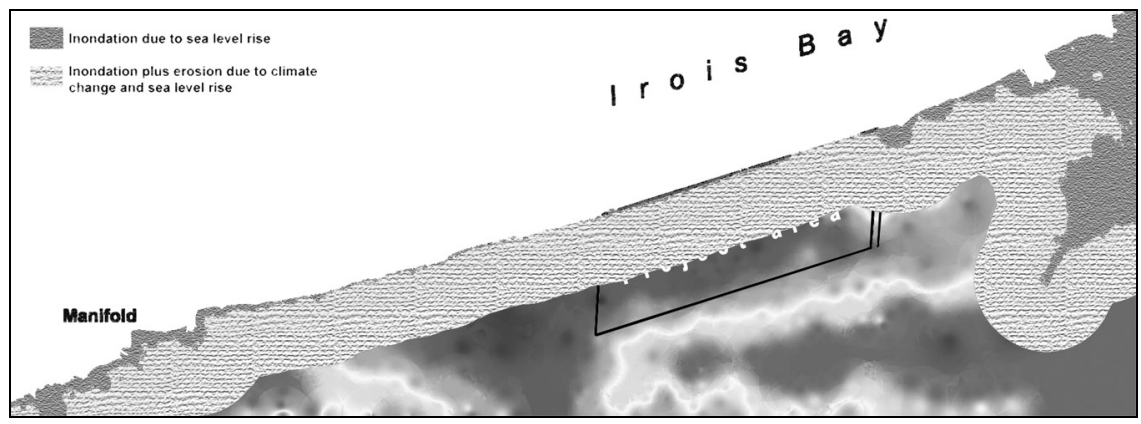

Figure 4: Inundation and erosion of the coastland at the Mont Pellier site due to sea level rise as simulated by CGCM1, coupled with the DEM, 2071. 


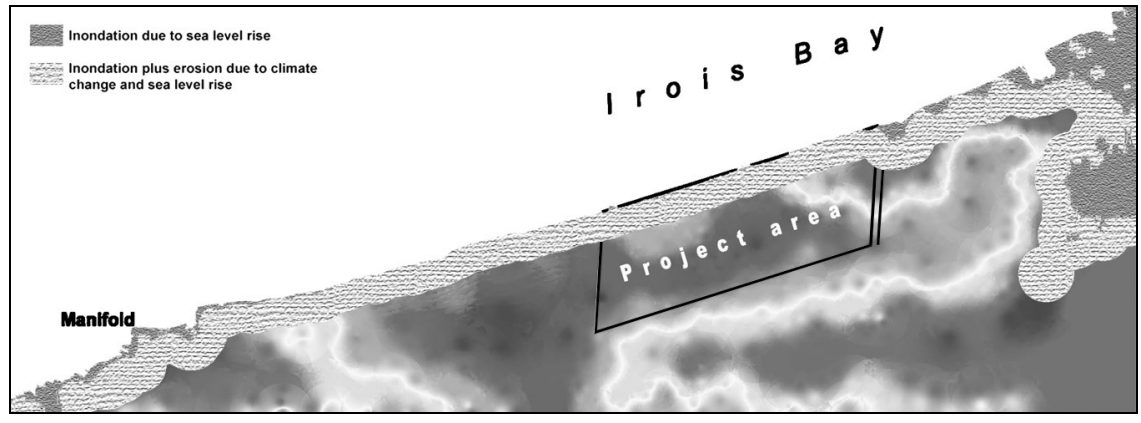

Figure 5: Inundation and erosion of the coastland at the Mont Pellier site due to sea level rise as simulated by HadCM3, coupled with the DEM, 2031.

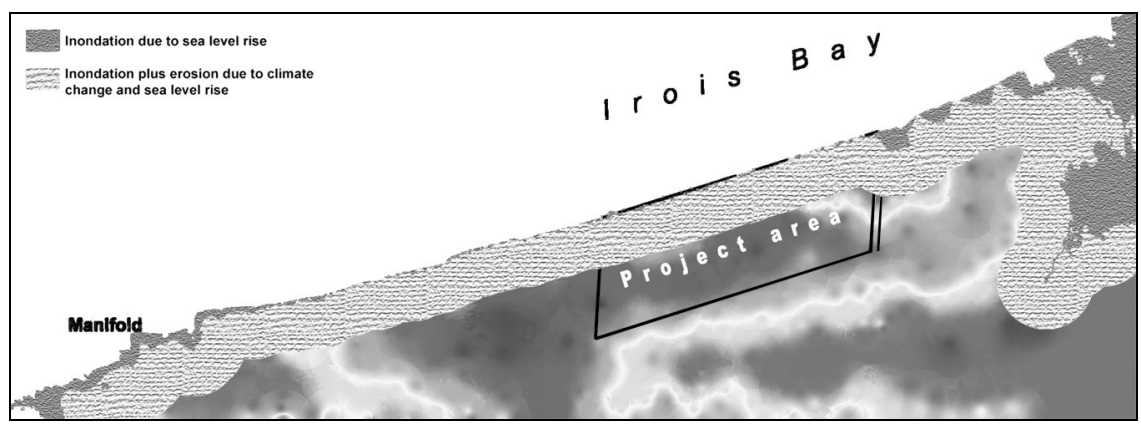

Figure 6: Inundation and erosion of the coastland at the Mont Pellier site due to sea level rise as simulated by HadCM3, coupled with the DEM, 2051 .

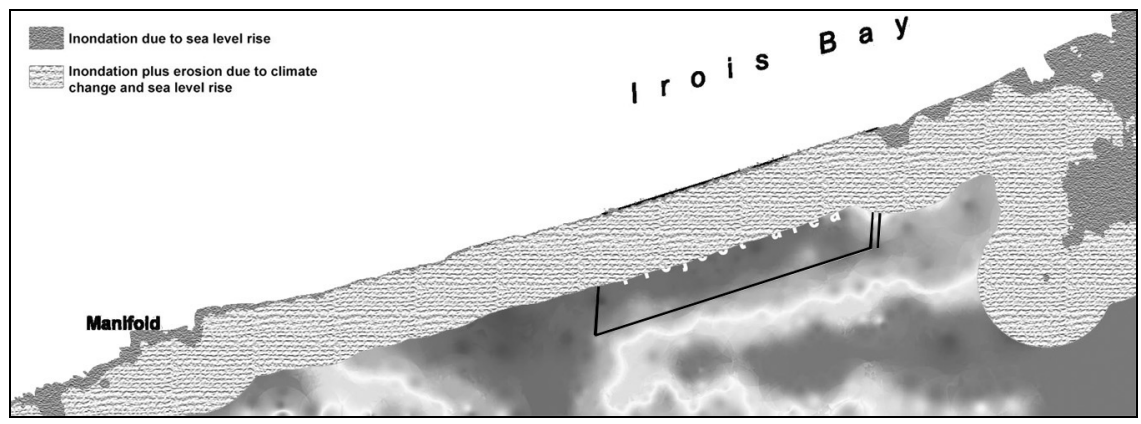

Figure 7: Inundation and erosion of the coastland at the Mont Pellier site due to sea level rise as simulated by HadCM3, coupled with the DEM, 2071 . 


\subsection{Proposed infrastructure and operations}

The proposed Trinmar Base facility at the Mont Pellier site lies about $7 \mathrm{~km}$ to the west-southwest of the present marine base at Point Fortin on Irois bay in the Gulf of Paria (Figure 1). The size of the proposed marine base is roughly 500 metres along the coastline and approximately 150 metres inland from the coast, giving a total area of about 7.0 hectares. In order to expand the size of the marine base, it is envisaged that a further 10, 400 square metres of the sea jutting out to 80 metres from the western extremity of the base plus a further 12,600 square metres jutting out to 40 to 100 metres from the eastern extremity, giving a total area of roughly 2.3 hectares, will be reclaimed from the sea, thereby giving a total area of about 9.3 hectares for the proposed marine base (Figure 1). Furthermore, port facilities, including dredged harbour, jetty and turning basin will extend a further 500 metres from the edge of the reclaimed area. It is further proposed to protect the port and harbour facilities by a series of rip-rap breakwaters, on which access roads are to be constructed, extending 500 metres out to sea on the western extremity and approximately 480 metres on the eastern extremity (Figure 1). At the entrance to the port further rip-raps, approximately 260 metres long and a channel entry point, approximately 200 metres wide, are to be constructed. It is proposed that the height of landfill and rip-raps will at least 3 metres above mean sea level (Narine Persad: Personal communication).

Based on available bathymetric data, the depth of the Gulf of Paria near the Mont Pellier site is about 5 metres at a distance of about 1 kilometre from the existing coastline (Figure 1). This will therefore require filling up to 8 metres at the far extremity of the harbour for the installation of breakwaters. The present unreclaimed site is characterized by very steep cliffs and bluffs, almost vertical in certain places, consisting of dense clayey materials. It is proposed that the land at the proposed site will be remodelled either by creating a series of terraces or by bulldozing back to the pipeline reserve, maintaining a grade of one in three, down to the coast where the land elevation is to be about 3 metres (Narine Persad: Personal communication). It is also proposed that the access road to the Mont Pellier marine base would be from the town of Cap-de-Ville across the bridge on the Cap-de-Ville River (Figure 1). It is not certain as to the exact location of the road. Two possibilities are the road is either built on a raised protected platform along the coast or further inland to reach the site at the back near the pipeline reserve (Narine Persad: Personal communication).

\section{Conclusions and recommendations: adaptation}

Based on the results and analyses of the preceding sections, it is evident that the proposed Trinmar base at the Mont Pellier Estate on the Gulf of Paria will be subject to the impacts of climate change and sea level rise in the future. The following then is a list of recommendations, at minimal, that need to be taken into consideration in the design and construction of Trinmar's marine base at the Mont Pellier Estate site: 
- In the event of land reclamation projects at the Mont Pellier Estate site, installations, including protective ripraps, landing platforms, jetties, access roads and on-land infrastructure facilities, should be designed so as to accommodate, at minimum a one and a half metre rise in sea level, encompassing climate-driven sea level rise and land subsidence.

- The ripraps and access roads and jetty that are to be located on reclaimed land should be designed to accommodate both the direct effects of sea level rise and the erosion of the coastline due to extreme weather conditions such as storm surges and heavy rains.

- The access road to the Mont Pellier site, from the Cap-de-Ville bridge crossing, should preferably be built, not along the coast, but inland to access the Mont Pellier Base at the back near the pipelines. If it is to be built along the coast, the design should take into account the inundation and erosion impacts described previously.

- It is imperative to take into account the inundation and erosion effects of climate change and sea level rise on the stability and integrity of the slopes immediately to the east of the site, up to the Cap-de-Ville River and immediately to the west of the site up to the Manifold. This would require engineering stabilisation works to protect the steep clayey slopes from slumping and erosion due to heavy rains and rising seas. If not, the integrity of the site may be compromised by inundation and erosion effects concentrated along the thalweg, behind the site, between the Cap-de-Ville River and the Manifold.

- It would be highly advisable to develop a coastal zone management plan, integrating the various land uses of the area around the Mont Pellier site to accommodate climate change and sea level rise.

\section{References}

[1] Intergovernmental Panel on Climate Change (IPCC), Climate Change 2001: Impacts, Adaptation, and Vulnerability. Contribution of Working Group 11 to the Third Assessment Report of the Intergovernmental Panel on Climate Change, (McCarthy, J.J., O.F. Canziani, N.A. Leary, D.J. Dokken, and K.S. White (eds.)). Cambridge University Press, Cambridge, United Kingdom and New York, N.Y., USA, 1032 p, 2001.

[2] El Fouladi, A., Hausse du Niveau Moyen Relatif de la Mer à Trinidad, Caraïbes : Évidence, Causes Probables, et Évaluation. Thèse de Doctorat, Département de géographie, Université de Montréal, Soumise, 2004.

[3] Singh, B. and A. El Fouladi, Vulnerability Assessment Study for the Relocation of PETROTRIN TRINMAR'S Operations Marine base to the Mt. Pellier Estate. PETROTRIN-HSE Report: 179 p., 2004.

[4] Singh, B., Climate-induced global changes in the southern Caribbean: Trinidad and Tobago. Global Planetary Changes. 15: 93-111, 1997.

[5] Bruun, P.T. and M.L. Schwartz, Analytical predictions of beach profile change in response to a sea level rise. Z. Geomorphol., N.F. Suppl., 57:33$50,1985$. 